\title{
Mixed-ligand copper(II) complexes of dipicolylamine and 1,10-phenanthrolines: The role of diimines in the interaction of the complexes with DNA
}

\author{
S RAMAKRISHNAN and M PALANIANDAVAR* \\ School of Chemistry, Bharathidasan University, Tiruchirappallli 620 024, India \\ e-mail: palani51@sify.com, palanim51@yahoo.com
}

\begin{abstract}
Mixed-ligand copper(II) complexes of the type $[\mathrm{Cu}($ dipica $)($ diimine $)]\left(\mathrm{ClO}_{4}\right)_{2}$, where dipica is di(2-picolyl)amine and diimine is 1,10-phenanthroline (phen), 5,6-dimethyl-1,10-phenanthroline $(5,6$ dmp), 2,9-dimethyl-1,10-phenanthroline (2,9-dmp) or dipyridoquinoxaline (dpq), have been isolated and characterized by analytical and spectral methods. The copper(II) complexes exhibit a broad band in the visible region around $675 \mathrm{~nm}$ and axial EPR spectra in acetonitrile glass $(77 \mathrm{~K})$ with $g_{\|}$and $A_{\|}$values of $\sim 2.22$ and $185 \times 10^{-4} \mathrm{~cm}^{-1}$ respectively, suggesting the presence of a square-based coordination geometry for the $\mathrm{CuN}_{5}$ chromophore involving strong axial interaction. The interaction of the complexes with CT DNA has been studied using absorption, emission and circular dichroic spectral methods and viscosity measurements. Absorption spectral titrations reveal that the intrinsic DNA binding affinities are dependent upon the nature of the diimine ligand: $\mathrm{dpq}>5,6-\mathrm{dmp}>$ phen $>2,9-\mathrm{dmp}$. This suggests the involvement of the diimine rather than the dipica 'face' of the complexes in DNA binding. An intercalative mode of DNA interaction, which involves the insertion of dpq and to a lesser extent the phen ring of the complexes in between the DNA base pairs, is proposed. However, interestingly, the 5,6-dmp complex is involved in hydrophobic interaction of the 5,6-dmp ring in the grooves of DNA. The large enhancement in the relative viscosity of DNA on binding to the dpq and 5,6-dmp complexes supports the proposed DNA binding modes. Further, remarkably, the 5,6-dmp complex is selective in exhibiting a positive-induced CD band on binding to DNA suggesting the transition of the B form of CT DNA to A-like conformation. The variation in relative emission intensities of DNA-bound ethidium bromide observed upon treatment with the complexes parallels the trend in DNA binding affinities.
\end{abstract}

Keywords. Mixed-ligand $\mathrm{Cu}(\mathrm{II})$ complexes; dipica and 1,10-phenanthrolines; DNA binding studies; CD spectroscopy.

\section{Introduction}

Studies of small molecules, which bind at specific sites along a DNA strand as reactive models for protein-nucleic acid interaction, provide routes toward rational drug design as well as means to develop sensitive chemical probes for DNA. Thus, a number of metal chelates are of current interest for important applications in nucleic acid chemistry as probes of DNA structure in solution, reagents for mediation of strand scission of duplex DNA under physiological conditions and chemotherapeutic agents and in genomic research. ${ }^{1-5}$ Over the past decade, there has been substantial increase in interest in the design and study of DNA binding properties of potential redox and spectroscopically active $\mathrm{Cu}(\mathrm{II}), \mathrm{Co}(\mathrm{III})$

Dedicated to the memory of the late Professor Bhaskar G Maiya *For correspondence and $\mathrm{Ru}(\mathrm{II})$ complexes $^{6-9}$ as new chemical nucleases $^{10-12}$ as they appear to be less readily repaired by DNA repair mechanism. ${ }^{13,14}$ Copper(II) complexes containing heterocyclic bases have received considerable current interest in nucleic acid chemistry due to their diverse applications following the discovery of the "chemical nuclease" activity of the $[\mathrm{Cu}$ $\left.(\text { phen })_{2}\right]^{+}$(phen $=1,10$-phenanthroline $)$ complex in the presence of hydrogen peroxide and a reducing agent by Sigman and coworkers. ${ }^{15}$ Substituents on the phen ring determine the nuclease activity of the complexes. ${ }^{14,16}$ Thus $\left[\mathrm{Cu}(2,9-\mathrm{dmp})_{2}\right]^{+}(2,9-\mathrm{dmp}=$ 2,9-dimethyl-1,10-phenanthroline) fail to cleave DNA. ${ }^{14}$ Interpretation of data based on DNA cleavage by $\left[\mathrm{Cu}(\text { phen })_{2}\right]^{+}$and design of efficient artificial nuclease require knowledge of the binding and kinetic mechanisms and the factors that determine the mode and extent of binding. We have illustrated the nuclease activity of these complexes using redox prop- 
erties of copper(II) bis-complexes of various methylsubstituted 1,10-phenanthrolines. ${ }^{16}$ Further, we have discovered the novel conversion of right-handed $B$ to left-handed $Z$ conformation on interacting calf thymus (CT) DNA with $\left[\mathrm{Cu}(5,6-\mathrm{dmp})_{2}\right]^{2+}(5,6-$ $\mathrm{dmp}=5,6$-dimethyl-1,10-phenanthroline), though the $Z$ form of natural DNA such as CT DNA would normally escape detection. ${ }^{16}$ Also it has been reportted that some ternary copper(II) complexes of phen have antitumour activity. ${ }^{17}$ The fibre EPR spectra of mixed ligand copper(II) complexes of amino acids and diimines have thrown light on the modes of binding of the complexes to DNA. ${ }^{18}$ Very recently, Chakravarty and coworkers have used several ternary copper(II) complexes of diimines like dipyridoquinoxaline (dpq) to cleave DNA by double-strand scission under physiological condition. ${ }^{19-21}$ Copper(II) complexes of tren-based tris-macrocycles have been also used as effective chemical nucleases. $^{22}$

In our laboratory, we have focussed our attention on various non-covalent DNA interactions (along outside of DNA helix, along major groove or minor groove, intercalation of aromatic heterocyclic rings between the DNA base pairs) of redox-active $\mathrm{Cu}(\mathrm{II}),{ }^{23,24} \mathrm{Ru}(\mathrm{II})^{25}$ and $\mathrm{Co}(\mathrm{III})^{26}$ complexes. The present work stems from our continued interest in defining and evaluating the key DNA binding interaction of simple and mixed ligand copper(II) complexes of 1,10-phenanthrolines and also from our present efforts to explore the relationship between structure and nuclease activity of copper(II) complexes of diimines and certain tridentate ligands. In this report we explore the DNA binding properties of a few mixed ligand copper(II) complexes of the type $[\mathrm{Cu} \text { (dipica)(diimine) }]^{2+}$, where dipica is the simple pyridine-based symmetric tridentate ligand and diimines are heterocyclic bases like phen, 2,9dmp, 5,6-dmp and dpq. A host of physical methods like absorption, emission, circular dichroic spectral studies and hydrodynamic measurements have been used to probe the effect of variously methyl substituted 1,10-phenanthrolines on the mode and extent of interaction of the complexes with CT DNA.

\section{Experimental section}

\subsection{Materials}

Copper(II) perchlorate (Aldrich), 1,10-phenanthroline, 2,9-dimethyl-1,10-phenanthroline (Merck), 5,6-dimethyl-1,10-phenanthroline, di(2-picolyl)amine (Aldrich) and calf thymus DNA (Sigma) were used as received. Ultrapure Milli Q water $(18.3 \mu \Omega)$ was used for all the experiments. Commercial solvents were distilled and then used for the preparation of ligands and complexes. The ligand dipyridoquinoxaline $(\mathrm{dpq})$ was prepared by a reported procedure. ${ }^{27}$

\subsection{Physical measurements}

Disodium salt of calf thymus DNA was stored at $4^{\circ} \mathrm{C}$. Solutions of DNA in the buffer $50 \mathrm{mM} \mathrm{NaCl} /$ $5 \mathrm{mM}$ Tris $\mathrm{HCl}(\mathrm{pH}, 7 \cdot 1)$ in water gave a ratio 1.9 of UV absorbances at 260 and $280 \mathrm{~nm}, A_{260} / A_{280}$, indicating that the DNA was sufficiently free from protein. ${ }^{28}$ Concentrated stock solutions of DNA $(13.5 \mathrm{mM})$ were prepared in buffer and sonicated for 25 cycles, where each cycle consisted of $30 \mathrm{~s}$, with $1 \mathrm{~min}$ intervals. The concentration of DNA was measured by using its extinction coefficient at $260 \mathrm{~nm}\left(6600 \mathrm{~cm}^{-1}\right)$ after $1: 100$ dilutions. Stock solutions were stored at $4^{\circ} \mathrm{C}$ and used over no more than 4 days.

Concentrated stock solutions of the copper complexes were prepared by dissolving the complexes in methanol and diluting suitably with the corresponding buffer to the required concentrations for all the experiments. For absorption, emission and circular dichroic spectral experiments, the DNA solutions were pretreated with the solutions of the complexes to ensure no change in their concentrations. The absorption spectra were recorded on a Varian Cary 300 Bio UV-Vis spectrophotometer using cuvettes of $1 \mathrm{~cm}$ path length.

Electron paramagnetic resonance spectra of the mixed ligand complexes were obtained on a Varian E 112 EPR spectrometer. The spectra were recorded for solutions of the complexes in acetonitrile: acetone $(4: 1 \mathrm{v} / \mathrm{v})$ solution at room temperature (RT) as well as at liquid nitrogen temperature $(77 \mathrm{~K})$. DPPH was used as the field marker.

Absorption spectral titration experiments were performed on a Varian Cary 300 Bio UV-Vis spectrophotometer by keeping the concentration of the complex constant while varying that of the nucleic acid. This was achieved by dissolving an appropriate amount of the complex and DNA stock solutions while maintaining the total volume constant $(1 \mathrm{ml})$. This resulted in a series of solutions with varying concentrations of DNA but with constant concentration of the complex. The absorbance (A) of the most red-shifted band of each investigated complex was 
recorded after successive additions of CT DNA pretreated with the complex.

Emission intensity measurements were carried out on a Jasco F 6500 spectrofluorimeter. Tris buffer was used as the blank to make preliminary adjustments. The excitation wavelength was fixed and the emission range was adjusted before measurements. DNA was pretreated with ethidium bromide in the ratio $[\mathrm{NP} / \mathrm{EthBr}]=1$ for $30 \mathrm{~min}$ at $27^{\circ} \mathrm{C}$. The metal complexes were then added to this mixture and their effect on the emission intensity was measured.

For viscosity measurements a Schott Gerate AVS 310 automated viscometer was thermostated at $25^{\circ} \mathrm{C}$ in a constant temperature bath. The concentration of DNA was $500 \mu \mathrm{M}$ in NP and the flow times were noted from the digital timer attached with the viscometer at different loadings of the complexes $(1 / R=$ $[\mathrm{Cu}] /[\mathrm{DNA}]=0-0 \cdot 5)$.

\subsection{Synthesis and characterization}

$2.3 \mathrm{a}$ Synthesis of $[\mathrm{Cu}$ (dipica)(phen $)]\left(\mathrm{ClO}_{4}\right)_{2}$ : This complex was synthesized as reported ${ }^{29}$ already.

2.3b Synthesis of $[\mathrm{Cu}($ dipica $)(5,6-\mathrm{dmp})]\left(\mathrm{ClO}_{4}\right)_{2}$ : This complex was synthesized by adding a solution of copper(II) perchlorate hexahydrate $(0.367 \mathrm{~g}, 1 \mathrm{mM})$ in aqueous methanol to a methanolic solution of 5,6dimethyl-1,10-phenanthroline $(0.226 \mathrm{~g}, 1 \mathrm{mM})$ and di(2-picolyl)amine $(0.133 \mathrm{~g}, 1 \mathrm{mM})$, and stirring the solution for $1 \mathrm{~h}$. The resulting solution was then filtered and kept aside for slow evaporation at room temperature. The blue crystalline solid that crystallized out was collected by suction filtration, washed with small amounts of cold methanol and then dried in vacuum. Analysis: Calc. $-\mathrm{C}, 47.34 ; \mathrm{H}, 4.08 ; \mathrm{N}$, $10 \cdot 22 \%$. Found - C, 47.31; H, 4.11; N, 10.28\%.

2.3c Synthesis of $[\mathrm{Cu}($ dipica $)(2,9-d m p)]\left(\mathrm{ClO}_{4}\right)_{2}$ : This complex was prepared by adopting the procedure used for the isolation of [Cu(dipica) (5,6-dmp)] $\left(\mathrm{ClO}_{4}\right)_{2}$ but by using 2,9-dimethyl-1,10-phenanthroline instead of 5,6-dimethyl-1,10-phenanthroline. Analysis: Calc. $-\mathrm{C}, 47.34 ; \mathrm{H}, 4 \cdot 12 ; \mathrm{N}, 10.22 \%$. Found - C, 47.31; H, 4.16; N, 10.18\%.

$2.3 \mathrm{~d}$ Synthesis of $[\mathrm{Cu}($ dipica $)(\mathrm{dpq})]\left(\mathrm{ClO}_{4}\right)_{2}$ : This complex was also isolated by adopting the procedure used for the preparation of $[\mathrm{Cu}$ (dipica) $(5,6-$ dmp)] $\left(\mathrm{ClO}_{4}\right)_{2}$ but using dipyridoquinoxaline (dpq) instead of 5,6-dimethyl-1,10-phenanthroline. Analy- sis: Calc. $-\mathrm{C}, 49 \cdot 27 ; \mathrm{H}, 3 \cdot 71 ; \mathrm{N}, 9.91 \%$. Found $49 \cdot 17 ; \mathrm{H}, 3 \cdot 68 ; \mathrm{N}, 9 \cdot 85 \%$.

\section{Results and discussion}

Mixed-ligand copper(II) complexes of the type $[\mathrm{Cu}$ (dipica)(diimine) $]\left(\mathrm{ClO}_{4}\right)_{2}$, where dipica is the $3 \mathrm{~N}$ ligand di(2-picolyl)amine and diimine is 1,10phenanthroline (phen) or 5,6-dimethyl-1,10-phenanthroline (5,6-dmp), 2,9-dimethyl-1,10-phenanthroline (2,9-dmp) or dipyridoquinoxaline (dpq), have been isolated as their perchlorate salts in good yields. They have been characterized using elemental analysis and spectral methods. The complexes are blue in colour and are soluble in water. The X-ray crystal structure of $[\mathrm{Cu}(\text { dipica })(\text { phen })]^{2+}$ reveals trigonal bipyramidal geometry for the $\mathrm{CuN}_{5}$ chromophore $^{29}$ and the other analogous dipica complexes are expected to have similar coordination geometry.

In buffer solution, all the complexes exhibit a very intense ligand-based absorption band in the UV region $(251-280 \mathrm{~nm})$. An intense band in the range 294-305 $\mathrm{nm}\left(\varepsilon_{\max }, 300-600 \mathrm{M}^{-1} \mathrm{~cm}^{-1}\right)$ has been assigned to $\mathrm{N}(\pi) \rightarrow \mathrm{Cu}$ (II) LMCT transition suggesting involvement in coordination of the diimine nitrogen atoms even in solution. Further, the complexes exhibit only one broad band in the visible region (678$683 \mathrm{~nm}$ ) with very low $\varepsilon_{\max }$ value (table 1 ), which is typical of a distorted square-based coordination geometry around copper(II). It is possible that on dissolution in Tris-buffer the complexes undergo a structural change from trigonal bipyramidal to square based geometry in which the dipica ligand is cis-facially coordinated (figure 1). Thus the frozen $\mathrm{CH}_{3} \mathrm{CN}$ solution EPR spectra of the complexes are axial with $g_{\|}>g_{\perp}>2.0$ and $G=\left(g_{\|}-2\right) /\left(g_{\perp}-2\right)=3.6$ supporting the square-based geometry around copper(II) in solution. A square-based $\mathrm{CuN}_{4}$ chromo-

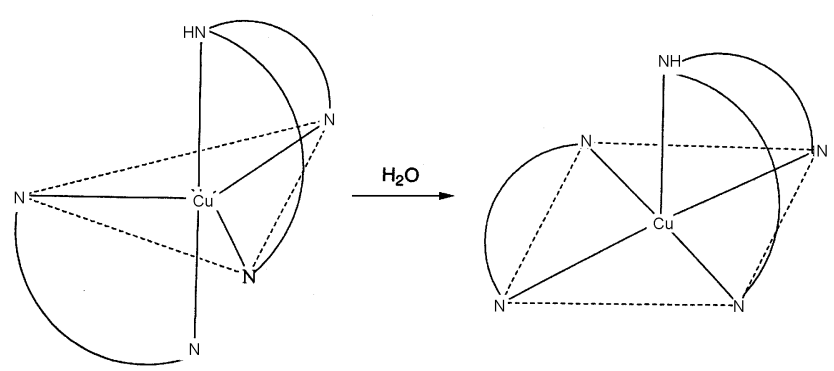

Figure 1. Schematic representation of change in geometry of $[\mathrm{Cu}(\text { dipica })(\text { diimine })]^{2+}$ complexes on dissolution in water. 
Table 1. Electronic absorption and EPR spectral properties ${ }^{\mathrm{a}}$ of $\mathrm{Cu}(\mathrm{II})$ complexes.

\begin{tabular}{|c|c|c|c|c|}
\hline \multirow{3}{*}{$\begin{array}{l}\text { Complex } \\
{[\mathrm{Cu}(\text { dipica })(\text { phen })]^{2+}}\end{array}$} & \multicolumn{2}{|c|}{$\lambda_{\max }$ in $\mathrm{nm}\left(\varepsilon, \mathrm{M}^{-1} \mathrm{~cm}^{-1}\right)$} & & \\
\hline & Ligand field $^{\mathrm{b}}$ & Ligand based $^{\mathrm{C}}$ & & pectra ${ }^{\mathrm{d}}$ \\
\hline & $683(51)$ & $\begin{array}{c}267(27425) \\
294 s h\end{array}$ & $\begin{array}{l}g_{\|} \\
A_{\|} \\
g_{\perp}\end{array}$ & $\begin{array}{l}2 \cdot 225 \\
188 \\
2.061\end{array}$ \\
\hline$[\mathrm{Cu}(\text { dipica })(5,6-\mathrm{dmp})]^{2+}$ & $680(52)$ & $\begin{array}{c}280(40645) \\
306 s h\end{array}$ & $\begin{array}{l}g_{\|} \\
A_{\|} \\
g_{\perp}\end{array}$ & $\begin{array}{l}2 \cdot 224 \\
188 \\
2 \cdot 061\end{array}$ \\
\hline$[\mathrm{Cu}(\text { dipica })(2,9-\mathrm{dmp})]^{2+}$ & $682(51)$ & $\begin{array}{l}251(34060) \\
\quad 312 \mathrm{sh}\end{array}$ & $\begin{array}{l}g_{\|} \\
A_{\|} \\
g_{\perp}\end{array}$ & $\begin{array}{c}2 \cdot 227 \\
180 \\
2 \cdot 038\end{array}$ \\
\hline$[\mathrm{Cu}(\operatorname{dipica})(\mathrm{dpq})]^{2+}$ & $678(50)$ & $\begin{array}{c}255(66733) \\
298 s h\end{array}$ & $\begin{array}{l}g_{\|} \\
A_{\|} \\
g_{\perp}\end{array}$ & $\begin{array}{l}2.225 \\
188 \\
2.058\end{array}$ \\
\hline
\end{tabular}

${ }^{\mathrm{a}}$ In buffer solution; ${ }^{\mathrm{b}}$ concentration $5 \times 10^{-3} \mathrm{M}$; ${ }^{\mathrm{c}}$ concentration $2 \times 10^{-5} \mathrm{M}$; ${ }^{\mathrm{d}}$ acetonitrile/acetone glass at $77 \mathrm{~K}, A_{\|}$in $10^{-4} \mathrm{~cm}^{-1}$

phore is expected to show $g_{\|}$value around 2.200 and $A_{\|}$value in the range $180-200 \times 10^{-4} \mathrm{~cm}^{-1}$ and strong axial interaction tends to increase the $g_{\|}$and decrease the $A_{\|}$value. ${ }^{30}$ Thus, it is evident that the observed EPR parameters $\left(g_{\|}, \sim 2 \cdot 23 ; A_{\|}, 180-188 \times 10^{-4} \mathrm{~cm}^{-1}\right)$ are consistent with the presence of a square-based $\mathrm{CuN}_{5}$ chromophore with strong axial interaction from the phen ring nitrogen atom.

When the dicationic copper(II) complex, interacts with the large polyanionic biopolymer calf thymus, (CT) DNA, it would replace two sodium ions in the compact (Stern) layer or the diffuse outer layer. The dicationic charge on the coordination sphere would lead to strong electrostatic interaction with the negatively charged phosphate group in the backbone of the DNA. The other possible noncovalent DNA interactions include hydrophobic interaction of the complexes in the DNA minor or major groove and partial intercalation of the diimine ligand into the base stack possibly from the major groove side. ${ }^{1,10}$ When the methyl substitution on the phen ring is varied, the size and shape of the mixed ligand complexes may be varied to fit with the DNA structure leading to specificity in DNA binding. While the dipica ligand may sterically clash with the DNA surface, the secondary amine hydrogen atom of the ligand may involve in hydrogen-bonding with the N7/O6 sites of the intrastrand guanine bases. ${ }^{31}$

\subsection{DNA binding studies}

3.1a Absorption spectral studies: Addition of increasing amounts of CT DNA to all the complexes shows a decrease in molar absorptivity (hypochromism, $\Delta \varepsilon, 6-15 \%$, table 2) of the $\pi \rightarrow \pi^{*}$ absorption band as well as a red-shift of a few $\mathrm{nm}(1-2 \mathrm{~nm})$ indicating the binding of the complexes to DNA in different modes and to different extents. The binding of an intercalative molecule to DNA has been well characterized by large hypochromism and significant red-shift due to strong stacking interaction between the aromatic chromophore of the ligand and DNA base pairs with the extent of hypochromism and red shift commonly consistent with the strength of intercalative interaction. ${ }^{32-34}$ But the magnitude of hypochromism and red-shift observed for all the copper complexes are lower than those observed for typical classical intercalators and partially intercalating metal complexes bound to CT DNA.

To enable quantitative comparison of the DNA binding affinities the intrinsic binding constants $K_{b}$ of the complexes for binding with CT DNA were obtained by using the equation,

$$
[\mathrm{DNA}] /\left(\varepsilon_{a}-\varepsilon_{f}\right)=[\mathrm{DNA}] /\left(\varepsilon_{b}-\varepsilon_{f}\right)+1 / K_{b}\left(\varepsilon_{b}-\varepsilon_{f}\right),
$$

where [DNA] is the concentration of DNA in basepairs, $\varepsilon_{a}$ is the apparent extinction coefficient obtai- 
ned by calculating $A_{\text {obs }} /\left[\right.$ complex], $\varepsilon_{f}$ corresponds to the extinction coefficient of the complex in its free form and $\varepsilon_{b}$ refers to the extinction coefficient of the complex in the bound form. Each set of data, when fitted to the above equation, gave a straight line with a slope of $1 /\left(\varepsilon_{b}-\varepsilon_{f}\right)$ and a $y$-intercept of $1 / K_{b}\left(\varepsilon_{b}-\varepsilon_{f}\right)$ and $K_{b}$ was determined from the ratio of the slope to intercept (figures 2 and 3). The intrinsic binding constants $K_{b}$ obtained for the complexes follow the order, $[\mathrm{Cu}(\text { dipica })(\text { dpq })]^{2+}>[\mathrm{Cu}(\text { dipica })(5,6-\mathrm{dmp})]^{2+}>$ $[\mathrm{Cu}(\text { dipica })(\text { phen })]^{2+}>[\mathrm{Cu}(\text { dipica })(2,9-\text { dmp })]^{2+}$ suggesting that the diimine rather than the dipica 'face' of the complexes is involved in DNA binding and that the coordinated dpq and phen rings are engaged in partial insertion in between the base pairs of DNA. The observed $K_{b}$ values are much lower than those observed for typical classical intercalators (EthBr, $K_{b}, 1.4 \times 10^{6} \mathrm{M}^{-1}$ in $25 \mathrm{mM}$ Tris- $\mathrm{HCl} / 40 \mathrm{mM}$

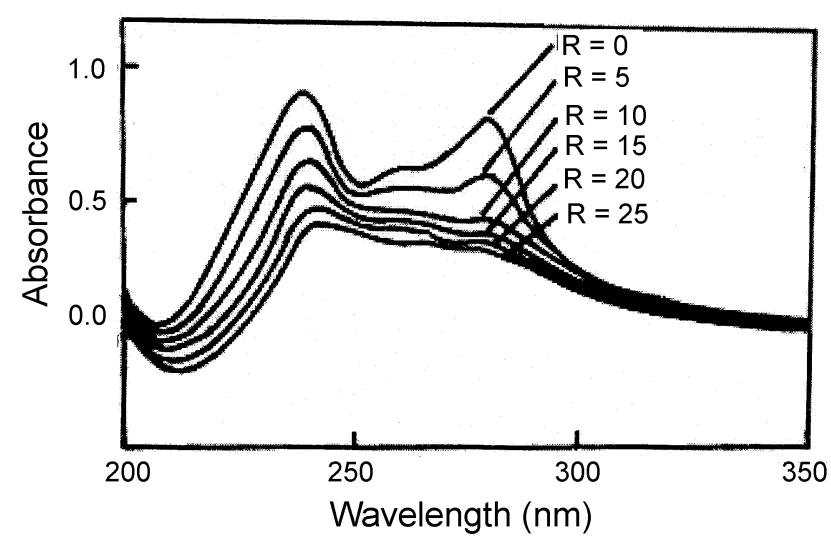

Figure 2. Absorption spectra of $[\mathrm{Cu}$ (dipica)(5,6dmp $)]^{2+}\left(3 \times 10^{-5} \mathrm{M}\right)$ in $5 \mathrm{mM}$ Tris- $\mathrm{HCl}$ buffer at $\mathrm{pH} 7 \cdot 1$ in the absence $(R=0)$ and presence $(R=5,10,15,20$, 25 ) of increasing amounts of DNA.

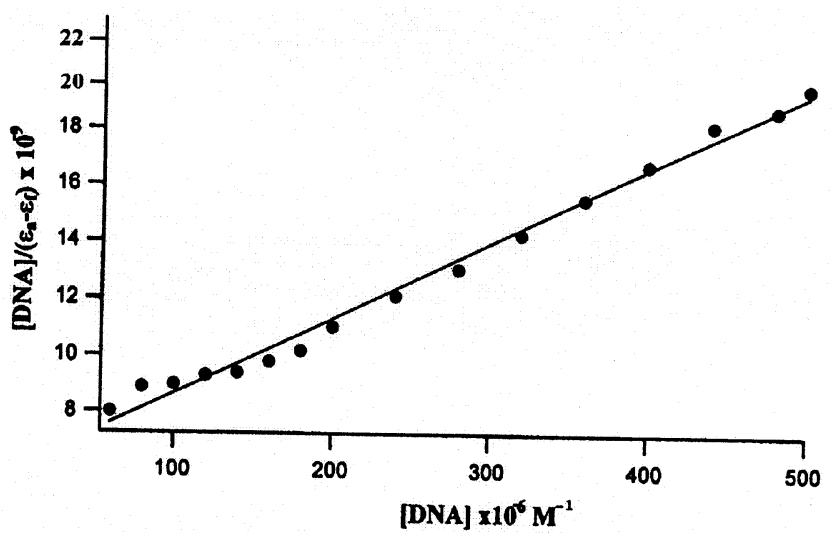

Figure 3. Plot of $\left[\mathrm{DNA} /\left(\varepsilon_{a}-\varepsilon_{f}\right)\right]$ vs [DNA].
$\mathrm{NaCl}$ buffer, $\mathrm{pH}$ 7.9) and partially intercalating metal complexes $\left(\left[\mathrm{Ru}(\mathrm{bipy})_{2}(\mathrm{dppz})\right]^{2+}, \quad \mathrm{dppz}=\right.$ dipyrido-[3,2-d: $\left.2^{\prime}, 3^{\prime}-f\right]$-phenazine, $K_{b}>10^{6} \mathrm{M}^{-1}$ ) bound to CT DNA. So it is obvious that the present complexes are involved in weaker intercalative interaction obviously due to the steric clash between the dipica ligand and DNA double helix. The strongest binding affinity exhibited by the dpq complex is expected on the basis of the additional aromatic ring of dpq, which enhances the extent of stacking of the diimine with the DNA base pairs. The introduction of methyl groups at the 2,9 positions of the phen ring lowers the DNA binding affinity suggesting that the methyl groups sterically hinder the partial intercalation of phen ring. Similarly, the introduction of 5,6-dimethyl groups on the phen ring would be expected to hinder the partial intercalation of the phen ring and hence decrease the DNA binding affinity. But the observed DNA binding affinity of the complex is higher than the phen analogue. It is proposed that the 5,6-dimethyl groups are involved in hydrophobic interaction with the hydrophobic DNA surface leading to enhancement in DNA binding affinity. Similar observations have been made by us earlier for $[\mathrm{Ru}(5,6-\mathrm{dmp})$ $\left.\left(\mathrm{NH}_{3}\right)_{4}\right]^{2+} 35$ and $\left[\left\{(5,6-\mathrm{dmp})_{2} \mathrm{Ru}\right\}_{2}(\mathrm{bpm})\right]^{4+}{ }^{36}$ complexes bound to CT DNA. Thus the pattern of methyl substitution on and modification of the phen ring dictate the DNA-binding structure and affinities of the present mixed-ligand complexes.

3.1b Viscosity measurements: Measurement of DNA viscosity is regarded as the least ambiguous and the most critical test of a DNA binding model in solution and affords stronger arguments for an intercalative DNA binding mode. ${ }^{37,38}$ The DNA viscosity is enhanced significantly due to complete or partial intercalation of drugs into DNA base stacking but it is slightly disturbed by electrostatic or covalent binding of molecules. ${ }^{39}$ To understand the nature of DNA binding of the mixed ligand copper(II) complexes, viscosity measurements were carried out on CT DNA by varying the concentration of the added complexes. The values of relative specific viscosity $\left(\eta / \eta_{0}\right)$, where $\eta$ and $\eta_{0}$ are the specific viscosities of DNA in the presence and absence of the complex respectively, are plotted against $1 / R(=[\mathrm{Cu}$ complex $] /[\mathrm{NP}])=0-0.5$ (figure 4$)$. The ability of the complexes to increase the viscosity of DNA depends upon the diimine ligand: $\mathrm{dpq} \geq 5,6-\mathrm{dmp}>$ phen and negligible changes are 
Table 2. Absorption spectral properties of $\mathrm{Cu}(\mathrm{II})$ complexes bound ${ }^{\mathrm{a}}$ to $\mathrm{CT}$ DNA.

\begin{tabular}{lcccccc}
\hline & \multicolumn{7}{c}{ Ligand-based } \\
\cline { 2 - 7 } Complex & $\lambda_{\max }(\mathrm{nm})$ & $R$ & Change in absorbance & $\Delta \varepsilon(\%)$ & Red shift $(\mathrm{nm})$ & $K_{b} \times 10^{3}\left(\mathrm{M}^{-1}\right)$ \\
\hline$[\mathrm{Cu}(\text { dipica})(\text { phen })]^{2+}$ & 267 & 25 & Hypochromism & 7 & 1 & $2 \cdot 7$ \\
{$\left[\mathrm{Cu}(\text { dipica) }(5,6-\mathrm{dmp})]^{2+}\right.$} & 280 & 25 & Hypochromism & 13 & 2 & $4 \cdot 4$ \\
{$\left[\mathrm{Cu}(\text { dipica }(2,9-\mathrm{dmp})]^{2+}\right.$} & 251 & 25 & Hypochromism & 6 & 2 & 1.6 \\
{$[\mathrm{Cu} \text { (dipica)(dpq) }]^{2+}$} & 255 & 25 & Hypochromism & 15 & 0 & $6 \cdot 5$ \\
\hline
\end{tabular}

${ }^{\text {a }}$ Measurements were made at $R=25$, where $R=$ [DNA]/[Cu complex], concentration of copper(II) complex solutions $=2.3 \times 10^{-5} \mathrm{M}(\mathrm{phen}), 2 \cdot 0 \times 10^{-5} \mathrm{M}(5,6-\mathrm{dmp})$ and $3 \times 10^{-5} \mathrm{M}(2,9-\mathrm{dmp}, \mathrm{dpq})$

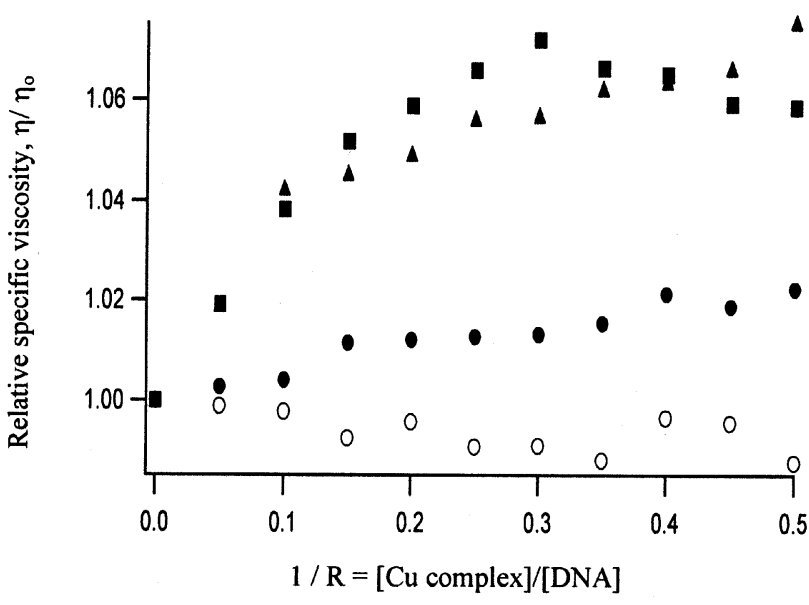

Figure 4. The effect of $\left[[\mathrm{Cu}(\text { dipica })(\mathrm{dpq})]^{2+}(\mathbf{\square}),[\mathrm{Cu}\right.$ $($ dipica $)(5,6-d m p)]^{2+}(\mathbf{\Delta}),[\mathrm{Cu} \text { (dipica)(phen) }]^{2+}()$ and $[\mathrm{Cu} \text { (dipica)(2,9-dmp) }]^{2+}(\bigcirc)$ on the viscosity of CT DNA; Relative specific viscosity vs $1 / R=[\mathrm{Cu}$ complex $] /[\mathrm{DNA}]$.

observed for the 2,9-dmp complex. These results parallel the hypochromism and $K_{b}$ values observed for the complexes (cf. above). The lengthening of DNA duplex occurs upon the partial insertion of phen and that of dpq more deeply between the DNA base pairs. Interestingly, the 2,9-dimethyl substitution on the phen ring in $[\mathrm{Cu}(\text { dipica })(2,9-\mathrm{dmp})]^{2+}$ complex appears to block the intercalative interaction strongly and hence the negligible changes observed in the relative DNA viscosity. This is in conformity with its lowest DNA binding affinity (cf. above). Similarly, the presence of methyl groups on the 5,6 positions of the phen ring would also sterically hinder the partial insertion of the phen ring in between the DNA base pairs, leading to no change in relative viscosity of DNA. However, interestingly, an increase in viscosity of DNA as much as for the dpq complex is observed. It appears that the effective lengthening of DNA duplex occurs on groove binding of the hydrophobically interacting 5,6-dmp complex as illustrated above. Thus the vis- cosity studies suggest that the central rings of dpq and phen are involved in partial intercalative mode of DNA binding, while the 5,6-dmp complex shows groove binding.

3.1c Circular dichroic spectral studies: Circular dichroic spectral techniques may give us useful information on how the helicity of the DNA chain influences the electronic transitions of a bound complex. The observed CD spectrum of calf thymus DNA consists of a positive band at $275 \mathrm{~nm}$ (UV: $\left.\lambda_{\max }, 260 \mathrm{~nm}\right)$ due to base stacking and a negative band at $245 \mathrm{~nm}$ due to helicity, which is characteristic of DNA in right-handed $B$ form. ${ }^{40}$ Thus simple groove binding and electrostatic interaction of a small molecules with DNA show less or no perturbations on the base stacking and helicity bands, while intercalation enhances the intensities of both the bands stabilizing the right-handed $B$ conformation of CT DNA as observed for the classical intercalator methylene blue. ${ }^{41}$ When the present series of complexes are incubated with CT DNA at the $1 / R(=[\mathrm{Cu}$ complex]/[DNA]) value of 2 , the $\mathrm{CD}$ spectrum of DNA undergoes changes in both positive and negative bands (table 3). The dpq, phen and 2,9-dmp complexes show slight decrease and increase in intensities respectively of the negative and positive bands suggesting slight changes in DNA helicity upon interaction with the complexes. On the other hand, interestingly, the 5,6-dmp complex shows a red-shift of nearly $10 \mathrm{~nm}$ on both the bands with increase and decrease in intensities respectively of the positive and negative bands (figure 5), which corresponds to induced CD on the hydrophobic interaction of 5,6-dimethyl groups with DNA. Such spectral changes are characteristic of $B$ to $A$ conformational change. The supporting spectral feature for this type of transition is the red-shift of the positive ellipticity band from 275 to $280 \mathrm{~nm} .{ }^{42}$ This wavelength region of the absorption spectrum due to 
$\pi \rightarrow \pi^{*}$ transition is quite sensitive to the increased positive base pair tilting of A DNA. Similar observations have been made for $\left[\mathrm{Co}(\text { bipy })_{2}(\mathrm{ip})\right]^{3+}$ and certain $\mathrm{Ru}(\mathrm{II})$ complexes bound to CT DNA. ${ }^{25,26}$

3.1d Competitive binding studies: Competitive ethidium bromide (EthBr) binding study has been undertaken to gain support for the above spectral and viscometric results. It involves the addition of the complexes to DNA pretreated with $\mathrm{EthBr}$ ([NP]/

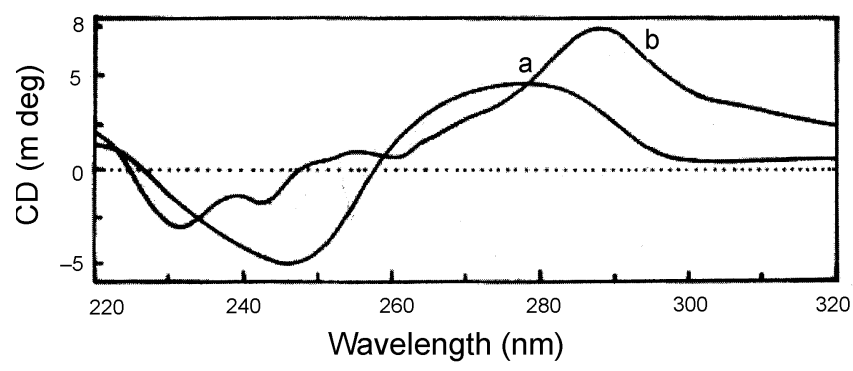

Figure 5. Circular dichroic spectra of calf thymus DNA in the absence (a) and presence (b) of $[\mathrm{Cu}($ dipica) $(5,6-$ dmp) $]^{2+}$.

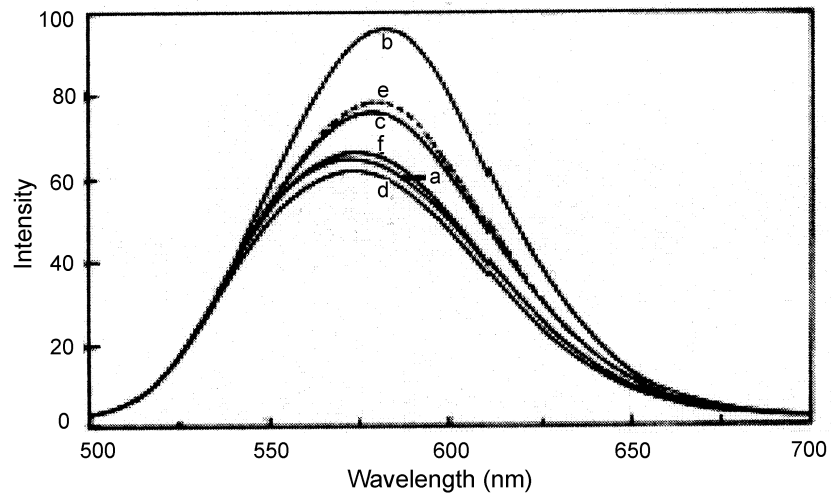

Figure 6. Emission spectra of ethidium bromide in the absence (a) and presence of CT DNA (b), DNA-EthBr + $[\mathrm{Cu}(\text { dipica })(\text { phen })]^{2+}(\mathrm{c}), \mathrm{DNA}-\mathrm{EthBr}+[\mathrm{Cu}(\text { dipica })(\text { dpq })]^{2+}$ (d), DNA-EthBr $+[\mathrm{Cu}(\text { dipica })(2,9-\mathrm{dmp})]^{2+}$ (e) and DNA$\mathrm{EthBr}+[\mathrm{Cu}(\text { dipica })(5,6-\mathrm{dmp})]^{2+}$ (f).

Table 3. CD parameters for the interaction of calf thymus DNA with copper(II) complexes.

\begin{tabular}{lcc}
\hline Sample & ${ }^{\mathrm{a}} \mathrm{CD}$ spectral bands $(\mathrm{nm})$ \\
\hline $\mathrm{CT}$ DNA & 245 & 277 \\
{$\left[\mathrm{Cu}(\right.$ dipica $)(\text { phen }]^{2+}$} & 246 & 277 \\
{$[\mathrm{Cu})(\text { dipica }(5,6-\mathrm{dmp})]^{2+}$} & 232 & 288 \\
$[\mathrm{Cu})($ dipica $)(2,9-\mathrm{dmp})]^{2+}$ & 251 & 267 \\
{$[\mathrm{Cu}(\text { dipica })(\text { dpq })]^{2+}$} & 247 & 281 \\
\hline
\end{tabular}

${ }^{a}$ Measurement made at $1 / R$ value of 2 , where $1 / R=$ $[\mathrm{Cu}] /[\mathrm{NP}]$; concentration of DNA solutions, $2.5 \times 10^{-5} \mathrm{M}$.

Cell path length, $1 \mathrm{~cm}$
[EthBr $]=1)$ and then the measurement of intensities of DNA-induced EthBr emission. Addition of a second molecule would quench the EthBr emission by either replacing DNA-bound $\mathrm{EthBr}$ (if it binds to DNA more strongly than EthBr) and/or by transferring the excited state electron to the added complex. The observed enhancement in induced emission intensity of EthBr bound to DNA decreases in the order, dpq $(109 \%)>5,6$-dmp $(92 \%)>$ phen $(63 \%)>2,9$ dmp (56\%) (figure 6), which is consistent with the results from spectral and viscosity measurements. This reflects the ability of the complexes to displace the DNA-bound $\mathrm{EthBr}$ and thus $[\mathrm{Cu} \text { (dipica)(dpq) }]^{2+}$ effectively hinders the enhancement in EthBr emission suggesting its strong competition with $\mathrm{EthBr}$ for the intercalative binding site. The incorporation of 2,9-dimethyl groups sterically hinders the partial intercalation of the phen moiety and permits the solvent water molecules to enter the DNA molecule and deactivate the exciplex. In contrast, interestingly, the 5,6-dmp complex, which is shown by viscosity measurements not to be involved in intercalative binding but report in groove binding, also hinders the enhancement in emission of DNA-bound EthBr very effectively. This is consistent with the conformational transition of DNA from the $B$ to the $A$ form induced by this complex (cf. above). The more rigid A helix is unable to accommodate an intercalating molecule like $\mathrm{EthBr}^{43,44}$ but is suitable for groove binding of the complex facilitated by the hydrophobic interaction of the 5,6-dimethyl groups with DNA.

\section{Conclusions}

The present study leads us to conclude that the $[\mathrm{Cu} \text { (dipica)(diimine) }]^{2+}$ complexes bind to CT DNA through their diimine rather than dipica 'face' and that the nature of the diimine - planarity and pattern of methyl substitution - dictates both their DNAbinding structure and affinity. Thus, when the diimine is phen and dpq with extended aromatic ring, partial intercalative interaction of the complexes to DNA base pairs is facilitated leading to enhancement in DNA-binding affinity. While 2,9-dimethyl substitution strongly interferes with the partial intercalation of the complex, 5,6-dimethyl substitution facilitates predominantly hydrophobic interaction leading to groove binding. The hydrodynamic studies show that $[\mathrm{Cu} \text { (dipica) }(5,6-\mathrm{dmp})]^{2+}$ effects an increase in viscosity as much as the partially intercalating 
$[\mathrm{Cu}(\text { dipica })(\mathrm{dpq})]^{2+}$ but higher than other complexes in the series supporting the proposed DNA-binding modes. A remarkable observation is that the 5,6dmp complex effects a $B$ to $A$ conformational change consistent with related spectral studies. We are making further efforts to understand the modes of DNA interaction by studying the abilities of the complexes to cleave plasmid DNA.

\section{Acknowledgements}

Board of Research in Nuclear Sciences, Department of Atomic Energy, Mumbai is gratefully acknowledged for financial support and a fellowship to VR. We thank Prof P Sambasiva Rao, Pondicherry University, Pondicherry for providing EPR facilities. University Grants Commission, New Delhi and Department of Science and Technology, New Delhi are gratefully acknowledged for funding through programs.

\section{References}

1. Dervan P B 1986 Science 4646232

2. Lu P, Zhu M L and Yang P 2003 J. Inorg. Biochem. 9531

3. Wu J Z, Li H, Zhang J G and Xu J H 2002 Inorg. Chem. Commun. 571

4. Hemmert C, Pitie M, Renz M, Gornitzka H, Soulet S and Meunier B 2001 J. Biol. Inorg. Chem. 614

5. Navarro M, Cisneros-Fajardo E J, Sierralta A, Fernadez-Mastre M, Silva P, Arrieche D and Marchan E 2003 J. Biol. Inorg. Chem. 8401

6. Liu J, Mei W J, Lin L J, Zheng K C, Chao H, Yun F $\mathrm{C}$ and Ji L N 2004 Inorg. Chim. Acta 357285

7. Chao H, Mei W J, Huang Q W and Ji L N 2002 J. Inorg. Biochem. 92165

8. Wu J Z and Yuan L 2004 J. Inorg. Biochem. 9841

9. Arounagiri S and Maiya B G 1996 Inorg. Chem. 354267

10. Pitie M, Horn V D J, Brion D, Burrows C J and Meunier B 2000 Bioconjugate Chem. 11892

11. Chand D K, Schneider H J, Bencini A, Bianchi A, Georgi C, Ciattini S and Valtancoli B 2000 Chem. Eur. J. 64001

12. Lamour E, Routier S, Bernier J L, Catteau J P, Bailly C and Vezin H J 1999 J. Am. Chem. Soc. 121862

13. Povirk L F 1991 Mutat. Res. 257127

14. Sigman D S, Graham D R, Aurora V D and Stern A M 1979 J. Biol. Chem. 25412269

15. Spassky A and Sigman D S 1985 Biochemistry 248050

16. Mahadevan S and Palaniandavar M 1998 Inorg. Chem. 37693

17. Ranford J D, Sadler P J and Tocher D A $1993 J$. Chem. Soc., Dalton Trans. 3393
18. Chikira M, Tomizava Y, Fukita D, Sugizaki T, Sugawara N, Yamazaki T, Sasano A, Shindo S, Palaniandavar M and Anthroline W E 2002 J. Inorg. Biochem. 89163

19. Santra B K, Reddy P A N, Neelakanta G, Mahadevan S, Nethaji M and Chakravarty A R 2002 J. Inorg. Biochem. 89191

20. Dhar S, Senapati D, Das P K, Chattopadhyay P, Nethaji M and Chakravarty A R 2003 J. Am. Chem. Soc. 12512118

21. Dhar S, Reddy P A N, Nethaji M, Mahadevan S, Saha M K and Chakravarty A R 2002 Inorg. Chem. 413469

22. Hegg E L and Burstyn J N 1998 Coord. Chem. Rev. 173133

23. Mahadevan S and Palaniandavar M 1998 Inorg. Chem. 373927

24. Palaniandavar M, Butcher $\mathrm{R} \mathrm{J}$ and Addison A W 1996 Inorg. Chem. 35467

25. Uma Maheswari P and Palaniandavar M $2004 J$. Inorg. Biochem. 98219

26. Tamilselvi $\mathrm{P}$ and Palaniandavar M 2002 Inorg. Chim. Acta 337420

27. Itoh K and Bernstein H J 1956 Can. J. Chem. 34170

28. Marmur J 1961 J. Mol. Biol. 3208

29. Huang G, Su C, Wang S, Liao F and Lin K $2000 \mathrm{~J}$. Coord. Chem. 43211

30. (a) Palaniandavar M, Somasundaram I, Lakshminarayanan M and Manohar H 1996 J. Chem. Soc., Dalton Trans, 1333; (b) Tamil Seliv P, Murali M, Palaniandavar M, Cockerling M and Henkel G 2002 Inorg. Chim. Acta 340139

31. Parkinson A, Hawken M, Hall M, Sanders K J and Rodger A 2000 Phys. Chem. Chem. Phys. 25469

32. Barton J K, Danishefsky A T and Goldberg J M 1984 J. Am. Chem. Soc. 1062127

33. Tysose S A, Morgan R J, Barker A D and Strekas T C 1993 J. Phys. Chem. 971707.

34. Kelly T M, Tossi A B, Mckonnell D J and Strekas T C 1985 Nucleic Acid Res. 136017.

35. Uma Maheswari P and Palaniandavar M 2004 Inorg. Chim. Acta 357901

36. Uma Maheswari P, Rajendiran V, Palaniandavar M, Parthasarathi R and Subramanian V Bull. Chem. Soc. Jpn (in press)

37. Norden B and Tjerneld T 1982 Biopolymers 211713

38. Lerman L 1961 J. Mol. Biol. 318

39. Raja A, Rajendiran V, Uma Maheswari P, Balamurugan $\mathrm{R}$ and Palaniandavar $\mathrm{M}$ (unpublished results)

40. Ivanov V I, Minchenkova L E, Schyolkina A K and Polytayer A I 1973 Biopolymers 1289

41. Collins J G, Shields T P and Barton J K 1994 J. Am. Chem. Soc. 1169840

42. Liu J G, Zhang Q L and Ji L N 2001 Transition Met. Chem. 26733

43. Mahadevan S and Palaniandavar M 1997 Inorg. Chim. Acta 254291

44. (a) Thomas T J and Bloomfield V A 1983 Nucleic Acids Res. 171919 ; (b) Gupta G, Dhingra M M and Sarna R H 1983 J. Biomol. Struct. Dyn. 1289 